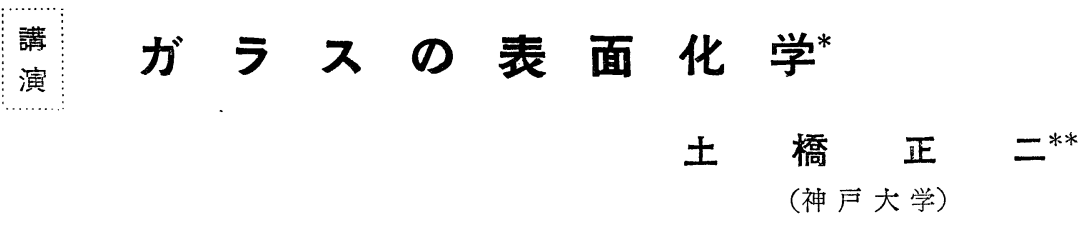

\section{I. ガラスの表面構造}

ガラス自身の内部構造飞関しては Zachariasen, Warren その他の人々のX線的研究とよって相当くわ しく明かとされている。それとよれば 4 価の正荷電を 持った珪素と 2 価の負荷電を持った酸素イオンとの間 飞作用する引力と同じ負荷電を持った酸素イオン同志 の間の反撥力との結果として, 酸素イオンは珪素の廻 りと等間隔酒列して正四面体の四つの角を占めてい る。こういう四面体が角を共有するようとなるとめる 種の重合が起り, 熔融物は結晶し難くなり, 過冷却を

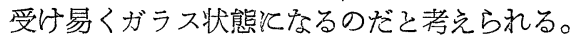

この場合に, $\mathrm{Si}^{4+}$ や $\mathrm{B}^{3+}$ のような正荷電をたくさ ん持った小さな正イオンは 4 個の $\mathrm{O}^{2-}$ に取巻かれる ことができるので，安定な院性の複イオンを形成する が，荷電の少いまたは半徍の大きい正イオンは充分な 引力を持っていないので, そのイオンに独特なグルー プを作るととができない。したがって，ガラスの網目 組織の中で $\mathrm{Na}^{+}, \mathrm{Ca}^{2+}$ 等は 2 次的な位置で满足しな ければならないわけである。

ところが，逆に $\mathrm{Na}^{+}$等は正イオンの電気力の関係 から強く束縛されていないので，荷電の大きい $\mathrm{Si}^{4+}$ 飞比べて動き易く，反応性飞富んでいるというととに なる。これが原因になって拉散移動を起したり，他の イオンと置きかわったりする現象が見られるわけであ る。

ここで，ガラスの塊をこわしたりすると，破壞面に 突き出ている原子価力（別の表現を使光ば表面陽イオ ンの不完全配位）のために，表面層注不安定な状態に なる。この余った力を満足させる一つの方法は，表面 に水の分子または油脂性の不純物を引きつけることで ある。この場合に，水は表面汲着されるだけでな く, ガラスと化学的洁合して $\mathrm{OH}$ 群を形成する。 もら一つの方法は, 不完全配位でも珪素の強い電場を 満足さすような陽イオンを表面に押し出す。すなわ ち，表面層の中でイオンの配置転換が起ることであ る。こういうふうと，表面層では表面エネルギーを極 小保たねね゙ならないていら制約のためと, ぞうして も組成構造が内部と異なる場合が起り得るのである。

* 昭和 28 年 7 月 18 日 大阪に括ける本会硝子部会講 演

*** 教授 理学博士
不完全配位を持った $\mathrm{Si}^{4+}$ イオンは，ガラス表面の エネルギーを著しく高い值に上げるので表面には存在 し得ないが，アルカリイオンはガラスの表面張力を低 下させることが Lyon ${ }^{1)}$ の研究から明がされてい る。

ガラス中に $1 \%$ 以下の酸化錫を加えると，金赤ガラ スの発色の際に金粒子の集合状態に大きな影響を和よ ぼしたり, $\mathrm{Pb}^{2+}, \mathrm{S} \mathrm{n}^{4+}, \mathrm{Ti}^{4+}, \mathrm{Bi}^{3+}, \mathrm{Sb}^{3+}$ 等を含む ガラス中に金，銀，銅等の金属が溶解したり，コバル ト，モリブデンを含むホーローが鋼鉄飞融着したりす る現象とついて考㝋た場合には，上にあげたようなイ オンがガラス中に統計的沟一飞分布していると考兄 たので忙とても説明できないので为って，ガラス中で 分子の再配列が起りイオンがガラス一金属界面に移 動して，界面を親金属性としていると考光ねばならな い。

ガラス表面に失透が起り易いのも，ガラス表面でア ルカリ成分が揮発してなくなり易いということ（そこ で泠却された時飞表面に和汓る膨脹係数の関係でしわ ができこれが失透のようと考学られる場合があるこ とを Gehlhoff ${ }^{2)}$ は指摘している。） または還元され るととによってアルカリが減少すること関連があ $ろ^{3)}$ 。

ガラス表面が親水性であるか䠅水性であるかといっ た問題について考觉て見よう。一般に，熔融してでき た珪酸塩ガラスの表面ではある程度の水分は附着して いるものと考党られるが，この水は $\mathrm{OH}^{-}$の形で $\mathrm{Si}$ イオンに結合し, ガラスの表面構造に影響を持ってく る。しかも, $\mathrm{OH}^{-}$将水素結合によってさらに他の物 質と附着する性質を持って来る。との水素結合の生成 のため林なガラズは水，アルコールまたは硫 酸等によって完全に濡れるようとなるのである。この 関係を模型的に書くと次のようとなる。<smiles>C[Si](O)(O)O</smiles>

(a)乾燥ガラス表面<smiles></smiles><smiles>C[Si](C)(P)P</smiles><smiles>C[Si](C)(F)[Si]([O-])(O)[OH2+]</smiles>

(b)濡れた表面 (c) HFとの反応
あるガラス試験管に微量の $\mathrm{K}_{2} \mathrm{Cr}_{2} \mathrm{O}_{7}$ を加えた濃硫 酸を入れて加熱する。クロム酸塩はガラス表面に附着 している有機物を酸化し，(a）のようなガラス表面に 
する。一部は水分がくっつき解離して (b)のようとな っている。この際, 硫酸中沉ずかの弗化物を加党て 特くそ(c) のようとなる。これは $\mathrm{OH}^{-}$と $\mathrm{F}^{-}$がイ オンの大きさ, 電荷, 分極性等が全く同じで同形置換 を起し得るからである (topatz, mica,apatite と执い てその例が見られる)。そこで $\mathrm{OH}^{-}$が曆とんで全部 F-で持きかわると水素結合を形成方可能性がなく なるので，硫酸によって濡らされる性質がなくなる。 乙かし，水が存在すると加水分解が起り， $\mathrm{OH}^{-}$基が 復洉してまた濡れるようになる。とこで，もし封管の 中で Fーが和きかわった状態汇なった場合には，長期 間にわたってガラス管の内壁は乞の反撥性を保持す る。

ガラス表面に普道の石けれは非常につき易く,つい た場合浪一般水をはじく性質を有するようになる そ考光られているが誤解が离る。一般にガラス表面は 負汇带電している場合が多く, パルミチン酸塩 $\mathrm{CH}_{3}$ $\left(\mathrm{CH}_{2}\right)_{14} \mathrm{COO}^{-} \mathrm{Na}^{+}$等が傍飞行っても負イオンの方が 強いた汹吸着されにくい。しかし，もしガラス表面 $\mathrm{KFe}^{3+}, \mathrm{Al}^{3+}, \mathrm{Zr}^{4+}$ なぞの原子価の高い陽イオンが ついているとパルミチン酸等はくっつき易くなり（d） のようにくっついて表面注 $\mathrm{CH}_{3}$ の蹯水性のために撥

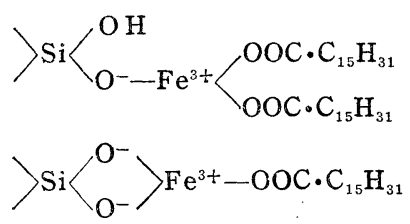

(d) $\mathrm{Fe}^{3+}$ と palmitate との反応

水性を有するょうとな る。このことは trimethyl lauryl ammonium イオンの場合を 䠸えと,さらによく 了解される。それはN が正の荷電を有するた めに (e)のようにな り，撥水性を持つと考 觉るとガラス表面の状 態がよくわかる。

专弪, W.I. Patno$\mathrm{de}^{5)}$ dimethyl silicon chloride $\mathrm{Cl}_{2}=$ $\mathrm{Si}=\left(\mathrm{CH}_{3}\right)_{2}$ でガラス 表面を処理して表面が 撥水性炕なるのは,(f)

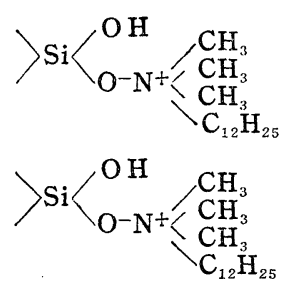

(e) Trimethyl-Lauryl Amine との反応<smiles>C[SiH](C)O[Si](C)(C)O[Si](O[SiH](C)C)(O[SiH](C)C)C(C)(C)C</smiles>

(f) Dimethyl Silicon Chloride との反応
で模型的示されるようなととが起るのだろうと考宇 ている。

以上の諸点を綜合的汇考无るとっ本来清浄なガラス
表面は親水性であり，何か他のすのがつくことによっ て柾水性に変るのだと考觉られる。

今末で考觉て来たガラスのように，ほとんど貴ガス 型のイオンのみを含さようなガラスに対しては, 結晶 状珪酸塩の結晶化学的模型から類推したガラス構造は よく岕てはまるが， $\mathrm{Sn}^{2+}, \mathrm{Sb}^{3+}, \mathrm{Pb}^{2+}$ 等のイオンを 含むガラス汶しては前にも触れたようにいるいろの 点で考光方を変觉柇洋ならない。こういうイオンを含 むガラスの翼常性に対して初めて説明を加光たのは Fajans そ Kreid1 ${ }^{6)}$ であり, $\mathrm{Sn}^{2+}, \mathrm{Sb}^{3+}, \mathrm{Pb}^{2+}$ のよ うに最外部の電子殼が満たされていないような構造を 持つ大きいイオン電場にもたらされた時には強く変 形し，その力の招よぶ範囲が貴ガス類似構造を有する イオンの場合とは非常に違うのだということが明か、 された。関連の㤁る元素の核外電子配列の必要部分を 書いたもの注第 1 表のようになる。ここで，鉛とつい

\section{第 1 表}

\begin{tabular}{|c|c|c|c|c|c|c|c|c|c|c|}
\hline \multirow{2}{*}{ 原子 } & \multirow{2}{*}{$\begin{array}{c}\text { 元素 } \\
\text { 名 }\end{array}$} & \multicolumn{9}{|c|}{ 核 外 電子 $\underbrace{\text { 配 列 }}$} \\
\hline & & $3 \mathrm{~d}$ & $4 \mathrm{~S}$ & $4 \mathrm{p}$ & $4 \mathrm{~d}$ & $5 \mathrm{~S}$ & $5 \mathrm{p}$ & $5 \mathrm{~d}$ & $6 \mathrm{~S} 6$ & $6 \mathrm{p}$ \\
\hline 22 & $\mathrm{Ti}$ & 2 & 2 & - & - & - & - & - & - & - \\
\hline 31 & $\mathrm{Ga}$ & 10 & 2 & 1 & - & - & - & - & - & - \\
\hline & $\mathrm{Ge}$ & 10 & 2 & 2 & - & - & - & - & - & 一 \\
\hline 33 & As & 10 & 2 & 3 & - & - & - & - & - & 一 \\
\hline 49 & In & - & - & - & 10 & 2 & 1 & - & - & - \\
\hline 50 & $\mathrm{Sn}$ & - & - & - & 10 & 2 & 2 & - & - & - \\
\hline 51. & $\mathrm{Sb}$ & - & - & - & 10 & 2 & 3 & - & - & 一 \\
\hline 81 & $\mathrm{Tl}$ & - & - & - & - & - & - & 10 & 2 & 1 \\
\hline 8 & $\mathrm{~Pb}$ & - & - & - & - & - & - & 10 & 2 & \\
\hline & $\mathrm{Bi}$ & - & - & - & - & - & - & 10 & 2 & \\
\hline
\end{tabular}

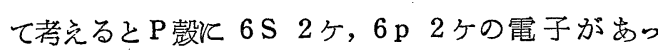
て, これが electron acceptor に与兄られ易いのであ るが， $\mathrm{Pb}^{2+}$ となった場合にはな特 $6 \mathrm{ST}$ 亿 2 ケの電子 がある故炕，負の電荷を持った $\mathrm{O}^{2-}$ が近づいて来た

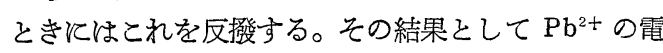
気力, もしくは原子価力はもはや空間汇等しく配置さ れているとはいえない。とで $\mathrm{Pb}^{2+}$ の二つ電子を反 撥している側では低い電子密度を持っていて, 構造は $\mathrm{Pb}^{4+}$ 似ている。反対信高い電子密度を持っている 側で性鉛原子の構造似似ている。したがって鉛イオン の結晶中，またはガラス中に挌ける分極は次のようと かける。

$$
\mathrm{Pb}^{2+}=\frac{1}{2} \mathrm{~Pb}^{4+}+\frac{1}{2} \mathrm{~Pb}
$$

こういうふらな変形したイオンがある場合と,強度， 粘度のような統計的な性質涂り大きい影響はない が，境界面に対する性質には著しい影響を竦よぼし， その結果として表面張力, 湿潤性, 摩嚓, 附着性ある いは表面の電気的性質等に非常に大きい影響が表われ て来る。 
Shartis Smock ${ }^{7)}$ とよれば， $\mathrm{Pb}$ を含さガラスは表 面張力の温度係数が正になることを見出している。と れは上飞述べたよ 万反，表面層飞非対称的集団が特別 の配向をしていることによって，それを打消すために 温度の増大と共沉たくさんのエネルギーが必要なのだ と考觉られる。

金属そガラスの間の附着の場合にも，今述べたよう 飞表面に非対称性イオンが外部向って原子のような 性質を持って配向しているので，その外側てつく金属 と金属結合を形成し得るから固くつくのだと考兄られ る。

ガラス表面の湿㵎性に対してもこの影響がよく現わ れ，非対称性イオンを多く含むような光学ガラスは水

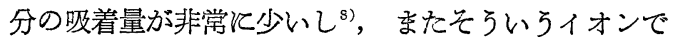
処理したガラス表面の水分の吸着量が少い9。

ガラス表面の摩擦現象伩対しても $\mathrm{Sn}^{2+}, \mathrm{Pb}^{2+}$ のよ ろなイオンは大きい効果を持っでり，はなはだしく 摩擦を減少せしめる。これを利用して $\mathrm{Hyde}^{10)}$ はガ ラス繊維の屈曲強度を大ならしめている。

\section{II. ガラスの表面反応}

（1）ガラス表面の脫アルカリ ガラス中のアル カリが非常に動きやすいととは既に述べたが，このア ルカリ成分の蒸気圧は相当高いので，ガラス表面から 蒸発する。特汇 $1000^{\circ} \mathrm{C}$ 位沈なる相当はげしくなる こてはよく知られている。これを利用して，さらと人 為的にガラス表面からアルカリを除いてやると，化学 的抵抗性や電気絶縁性を改善するばかりでなく，衝撃 強度や引搔き硬度のような機械的性質に大きな影響を 特よぼす。

脱アルカリを行わせる方法としては燃焼ガスにさら す方法, 酸性蒸気と反灾さす方法等いろいろあるが, 特に最近行われた面白い方法はガラス表面にカオリン 粉末の泥を塗って $400^{\circ} \mathrm{C} て ゙ 3$ 時、間位熱した後に泥を 洗い取ると

$\mathrm{Na}^{+}$ガラス $+\mathrm{H}^{+}$粘土 $=\mathrm{H}^{+}$ガラス $+\mathrm{Na}^{+}$粘土 の反応によりガラス表面のアルカリが除かれて化学的 耐久性が非常に増大するという報告が Weyl 等 ${ }^{11}$ V よりなされて実用化されている。

（2）ガラス表面で起る還元現象 銅, 銀, 鉛等 の重金属イオンを含むガラスは, 高温度で表面を還元 性のガスにさらすと表面だけが還元されてラスターが できるので，ガラス工芸品を作るのに利用される。

Zsigmondy $^{12)}$ は Pd, Cd, Bi の湖酸塩を還元する 法, Franchet ${ }^{13)}$ は重金属をガラスまたは釉薬の中に 混ぜて入れて置くか，金属化合物を表面渀込むかて て後汇還元する方法, Müller ${ }^{14)}$ は $\mathrm{Cu}, \mathrm{Ag}, \mathrm{Bi}$ の化 合物を含むガラスを使い， Land ${ }^{15)}$ は PbO のような
還元され易い金属酸化物を含をガラスを使って還元性 ガスにさらすととにより，ガラスの上隹属的ラスタ 一を作る実騟を行っている。Bastress ${ }^{16)}$ は Ag, Bi, $\mathrm{Pb}, \mathrm{Sb}$ の酸化物を含さ珪酸塩, 碵酸塩, 硼珪酸塩招 よびある種の燐酸塩ガラスを水素で還元する場合の条 件を系統的にくわしく研究し， $\mathrm{Ag}$ の場合は $100^{\circ} \mathrm{C}$ 以 下でも, Bi 約約 $200^{\circ} \mathrm{C}, \mathrm{Pb}$ 約 $350^{\circ} \mathrm{C}, \mathrm{Sb}$ 約 $400^{\circ} \mathrm{C}$ でそれぞれ還元されることを明かてている。

（3）ガラス表酒に金属や化合物过析出させる方法 これとは液相より行5方法と, 高真空中で気相から析 出さす方法との三つに大別される。

液相より銀を析出させて鏡を作る方法は，ずいぶん 昔よりいろいろと研究され，鍍銀前とガラス表面を塩 化第 1 錫孔たは塩化第 1 テタン溶液で迈理して就くを 銀のガラスへの接着が非常によくなる。この点につい

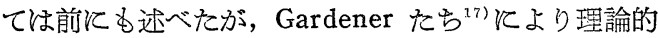
な検討と共汇詳細な薬品の処方と結果が発表せられて いる。銓のガラス表面上への析出とついてるいるいる あるが，Volmer ${ }^{18)}$ とよればガラス面上薄い銀の膜 を作り，この触煤作用により銅の強い膜をつけ得るこ とを述べている。金，白金のガラス表面上への析出に ついても Schweig'19) のくわしい研究があるが，析出 させる液つ処方と方法等よりる，析出された金属がガ ラス表面上によく附着するかどうかの方が閭題になる ようである。

気相より析出させる方法としては, $\mathrm{AsH}_{3}, \mathrm{Ni}(\mathrm{CO})_{4}$ 等の分子がガラス壁汇当って鏡の形で金属定析出する ことはよく知られているが，レンズ，プリズム等の反 射防止膜の形成の問題飞関連して $\mathrm{MgF}_{2}, \mathrm{NaAlF}_{6}$ の ような化合物の真空蒸着が盛ん行われているが20), このようなハロゲン化物はガラスの構造と連続した組 織を作って接着が行われるのだらうと考觉られる。 $\mathrm{Scott}^{21}$ は SiO を真空中で蒸発してアルミニウム鏡 の表面保護膜として利用している。

（4） ガラス表面における塩基置換反応こうい 万反応はガラスばかりでなく，天然をたは人工のゼオ ライトでよく見られる反応である。前化 Kreial 等ね ガラス中の $\mathrm{Na}^{+}$と荷電就よびイオンの大きさを等し くするもの海簡汇物きかわるが，異なるるのは困難 であると述べているが，第 2 表行示したようと $\mathrm{Na}^{+}$ そ $\mathrm{Ag}^{+} \mathrm{Na}^{+}$と $\mathrm{Li}^{+}$との半径の差はたいして違いがな いのに $\mathrm{Ag}^{+}$は入り易く $\mathrm{Li}^{+}$は入りにくいという点は 理解しにくい。少し例は異なるが aluminasilicate で ある pyrophilliteで $\mathrm{Al}$ のかわりと6 配位の $\mathrm{Mg}, \mathrm{Fe}$, Co 恃入り得るが, 4 配位つ $\mathrm{Zn}^{2+}, 8$ 配位の $\mathrm{Ca}^{2+}$, $\mathrm{Cd}^{2+}$ は入り得ないという例がある。これらのことを 考光合わすと $\mathrm{Na}^{+}$と $\mathrm{Ag}^{+}$は配位数が大体同じそ考 えられるので入り易く， $\mathrm{Li}^{+}$は配位数が異なるので入 
りにくいのだ考党た方が良いようと思われる。しかし ながら，温度が上ると塩基置換は非常に楽になり，イ オンの再配列飞伴って $\mathrm{Ti}^{4+}, \mathrm{Sn}^{4+}$ のような 4 価イオ ンでさへアルカリの代りに入るようとなる。

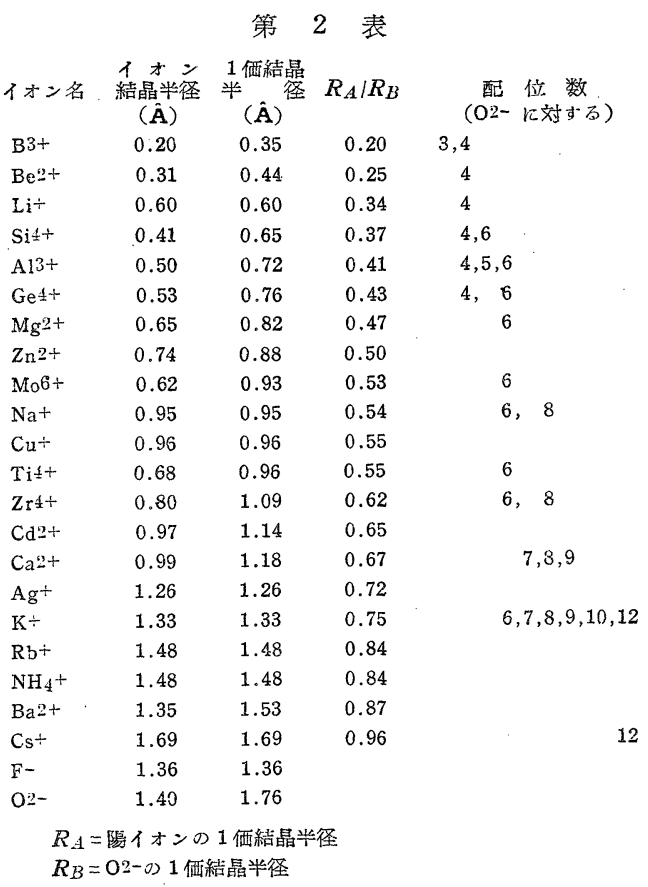

こういう塩基置換反応を起し易いことはガラスの特 長の一つであり, 実際にガラスを使用する場合には注 意しなければならない。例えば，有機化学でアルカリ

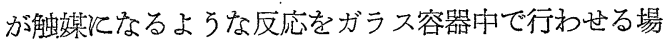
合, コロイドの研究の場合, 微生物を取扱う場合等に は充分の注意が必要である。

（5）ガラス表面とアルカリ溶液との反応 ガラス表面汶対するアルカリ溶液の作用については 多くの研究があるが，ガラス瓶の洗滌の場合にアルカ リを使ったとき瓶の損傷が多いのでそれを防止する工 夫がなされている。Cooper ${ }^{22)}$ はアルミ酸塩を加光, Wegst ${ }^{23)}$ はベリリウム化合物を加えている。これに より $\mathrm{Be}^{2+}$ そ $\mathrm{Al}^{3+}$ はガラス表面とアルカリとの間の 化学反応の速度を低下させる負触媒であることがわか った。またガラスエナメルの耐アルカリ性を增大さす ため使われる $\mathrm{Ti}^{4+}, \mathrm{Zr}^{4+}, \mathrm{Th}^{4+}, \mathrm{Ta}^{5+}, \mathrm{Nb}^{5+}$ も, 皆これと同じ作用を有するるのと侾られる。

\section{結語}

ガラス表面では，表面エネルギーを極小飞保たねば ならないという条件があるために，上述べたように 種々特殊な性質を示す。統計的と考光たガラス内部の
構造とは随分違ったような場合もあるが，時には表面 の研究からガラス内部の模様を推察して行く方法も可 能であるとすら考克られる場合もあるよう飞思われ る。こらいう点からガラス表面の問題をとりあげて見 た次第である。

な和紙面の都合上ガラス表面の性質を研究する種々 の方法についての記述を省略した。

$$
\text { 文献 }
$$

1) K.C. Lyon, J. Amer. Ceram. Soc., 27186 (1944)

2) G. Gehlhoff, Lehrbuch der Technischen Physik III. Die Physik der Stoge (1928); M. Thomas, J. Soc. Glass Techn., 20152 (1936)

3) P. Villard, Compt. Rend., 189969 (1929) ; M.A. Foëx, Compt. Rend., 203875 (1936)

4）土橋正二, 䉥協, 50 448（昭 17）

5) W.I. Patnode, U.S. Patent 2306222 (1942)

6) K. Fajans \& N.J. Kreidl, Glass Scince Bull., 147 (1947) ; J.Aner. Ceram. Soc., 31 105 (1948)

7) L. Shartis \& A.W. Smock, J. Amer. Cer. Soc., 30130 (1947)

8) D. Hubbard, J. Res. Nat. Bur. Standards, 36365 (1946)

9) M.K. Roman, E.C. Marboe \& W.A. Weyl, Trans. Soc. Glas Techn., 32247 (1948)

10) J.F. Hyde, U.S. Patent 2315259 (1943)

11) H.S. Williams \& W.A. Weyl, Glass Ind.,

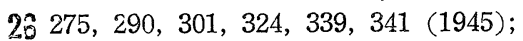
F.R. Matson, Glass Science Bull., 487 (1946)

12) P. Zsigmondy, Sprechsaal, 27 123, 147, 175, 201, 227 (1894)

13) L.Franchet, Sprechsaal, 30675 (1906); 40 450 (1907)

14) B. Müller, Sprechsaal, 44130 (1911)

15) E.H. Land, US. Patent 2319816 (1943)

16) A.W. Bastress, J. Amer. Cer. Soc., 3052 (1947)

17) I.C. Gardner \& F.A. Case, Cireular of the. Bureau of Standards No.389 (1931)

18) M. Volmer, German Patents 157379 (1921) 390145 (1924) 412322 (1945)

19) B. Schweig, Glass Ind., 24353 (1940)

20) J. Strong, J. Optical Soc. of Amer., 2673 (1936) ; C.H. Cartwright \& A.F. Turner, Bull. Amer. Phys. Soc., 1310 (1938), 148 (1939)

21) N.W. Scott, J. Optical Soc. of Amer., 36 711 (1946)

22) W.C. Cooper, U.S. Patent 2241984 (1944)

23) F. Wegst \& L.R. Bacon, U.S. Patent 2419805

$(8 / 5 / 53$ 受付 $)$ 